\title{
Discovering Distinctive Street Patterns of Snatch Theft through Crime Prevention through Environmental Design
}

\author{
Siti Rasidah Md Sakip \\ Department of Landscape Architecture, Faculty of Architecture, Planning and Surveying, \\ Universiti Teknologi MARA Perak Branch, Seri Iskandar Campus, 32610, Perak, Malaysia \\ Green Safe Cities Research Group, \\ Universiti Teknologi MARA, Shah Alam Campus,40450, Selangor, Malaysia \\ sitir704@uitm.edu.my \\ Tel: 019-2798594
}

\begin{abstract}
The theft crime rate in Malaysia for 2010 and 2015 is experiencing an increase in the rate of decline. This high-crime activity depends on an opportunity to commit a crime at the time of the incident. Thus, this paper is aimed at discovering distinctive street patterns of snatch theft through crime prevention through environmental design (CPTED). This research is a qualitative approach by field observation to investigate the physical environment of the snatch theft hotspot area. The finding indicates the three main principles of CPTED, which are surveillance, access control and territoriality contributed to snatch theft crime incidence.
\end{abstract}

Keywords: Snatch theft; Street; Environment setting; CPTED

eISSN: 2398-4287 @ 2019. The Authors. Published for AMER ABRA cE-Bs by e-International Publishing House, Ltd., UK. This is an open access article under the CC BYNC-ND license (http://creativecommons.org/licenses/by-nc-nd/4.0/). Peer-review under responsibility of AMER (Association of Malaysian Environment-Behaviour Researchers), ABRA (Association of Behavioural Researchers on Asians) and cE-Bs (Centre for Environment-Behaviour Studies), Faculty of Architecture, Planning \& Surveying, Universiti Teknologi MARA, Malaysia.

DOI: https://doi.org/10.21834/e-bpj.v4i12.1905

\subsection{Introduction}

Snatch theft is defined as a criminal act of stealing the property of other people by engaging rob-and-run tactics (Yew, 2012). It is not uncommon that the offenders operate most of the incidents on a motorcycle which is more comfortable to allow them to escape and safe more time without their face being recognized by the public. The tactic of snatch theft occurs in an instant. There will be no verbal communication occurs between the offender and the victim before the robbery (Monk, Heinonen, \& Eck, 2010). The most common purse-snatching incidents are that there will be two thieves riding a motorcycle, speed up towards a victim from behind where the passenger on the back snatches' valuable items such as a purse, handbag, or cellular phone (Mustafa \& Sakip, 2017). The crime index rate, especially snatch theft, is worsening in the recent few years. Snatch theft in Malaysia by the year 2010 until 2015; the crime rates have been fluctuating. Among the 14 states in Malaysia, four major cities with the high number reported cases of snatch theft which are in Selangor, Kuala Lumpur, Penang and Johor with 4,687 cases, 5,553 cases, 1,953 cases, and Johor with 298 cases respectively (PDRM, 2016). These cities are known as the major cities in Malaysia. Cities are becoming more attractive towards people from rural areas due to their economic and job opportunities. Therefore, crime prevention and common crimes of opportunities such as snatches should be address and target in urban planning. Thus, this research paper is aimed at discovering distinctive street patterns of snatch theft through crime prevention through environmental design (CPTED).

eISSN: 2398-4287 ( 2019 . The Authors. Published for AMER ABRA cE-Bs by e-International Publishing House, Ltd., UK. This is an open access article under the CC BYNC-ND license (http://creativecommons.org/licenses/by-nc-nd/4.0/). Peer-review under responsibility of AMER (Association of Malaysian Environment-Behaviour Researchers), ABRA (Association of Behavioural Researchers on Asians) and cE-Bs (Centre for Environment-Behaviour Studies), Faculty of Architecture, Planning \& Surveying, Universiti Teknologi MARA, Malaysia. DOI: https://doi.org/10.21834/e-bpj.v4i12.1905 


\subsection{Literature Review}

In an urban area, most of the land uses are commercial areas. It was found that commercial-only areas have higher crime (Anderson, Macdonald, Bluthenthal, \& Ashwood, 2013). A commercial district that is busy during the daytime will have low public activity, especially after office hours and become quiet, crime-prone areas during the night (Chowdhury, 2014). While most streets are safe to walk, downtown areas that are surrounded by entertainment facilities such as discos and bars tend to become populated with less desirable people after midnight. It is better to avoid these areas late at night if possible (OSAC, 2015). Most of the crime-prone regions tend to have factors of low traffic, less movement of people and poor condition of street lighting (Chowdhury, 2014). One of the elements shows that the volume of pedestrian could influence street crime to occur. Other than having less movement of people, street robbery such as snatch theft could work even there is a high density of people. This is because the offenders tend to be part of the people, which as if they belong to the place and able to escape by blending with the crowds (Monk et al., 2010). The relationship between density and crime has been quite ambiguous. There are some areas nearby the commercial and public spaces identified as crime-prone locations due to the existence of potential sources of accessible escape routes for the criminals (Chowdhury, 2014). This shows that land use could also be identified as one of the crucial factors for high crime rate until it becomes crime hotspot due to the existence of connectivity value and high integration of the area (Faizah, 2015).

The physical features existence increases the site visibility such as unobstructed windows, and well-lit areas and features that can block views are absence, for example, solid boundary walls, dense vegetation can help mitigate crime (Liggett, Loukaitou-sideris, Iseki, \& Candidate, 2003). This contributes to crime because the absence of these features can allow natural surveillance of the streets, thereby discouraging criminals from committing any offences there (Chowdhury, 2014). The connection between physical environment and crime in recent decades has become more noticeable since more people are using cameras, fences, locks, hostile vegetation implementation, and alarm operation. The physical environment tends to be more important than the social context when it comes to the crime reduction opportunities because elements that are involved in physical design able to be modified through planning and design (Abdullah, Razak, Salleh, \& Sakip, 2012).

There are numerous literature has shown that specific physical attributes such as "negative" land uses, the street layout that generates different escape routes, environmental disrepair and desolation, and physical features that block visibility and surveillance can encourage high crime incidence (Liggett et al., 2003). As cited by Greenberg and Rohe (1984) stated that the built environment design could affect crime through its effect on the degree of access, ease of entrance and exit, and surveillance (Greenberg \& Rohe, 1984). The offence may be reduced, if the physical features are being controlled, which includes, the improvement of the street lighting, increase the use of shared public spaces, the number of families per entrance and number of apartments per floor is reduced, zones from public to private hierarchy are created, and use of symbolic barriers in housing developments are increased (Nubani \& Wineman, 2005).

Street networks influence the movement patterns, awareness space and criminals target choices, especially those who are using automobiles or street-level public transit (Beavon, Brantingham, \& Brantingham, 1994). This indirectly shows that the individual activities are influenced by the formation of the built environment (Davies \& Johnson, 2015). The relationship between urban form and crime always related to the linkage of the street pattern. The street linkage defines as a path moving from any two or more locations which are the fundamental element for pedestrians and vehicular movement in an urban area. The relationship between streets and crime has existed for a long time. Within a criminal's awareness space, most of the target victims are selected. It is considered that street connections would be partly responsible for snatching occurrences since most of the snatches occurrence happened the on streets (Fujii, Sasaki, \& Kishimoto, 2013). It is definite from the literature of criminology that the favourable environmental circumstances form leads to criminal activity patterns where the street networks influence the publics' mobility patterns (Lee, 1970; Lowe \& Moryadas, 1975; Thomson, 1977). The paths by which criminals frequently travel impact their recognition of potential targets (P. Brantingham \& Brantingham, 1984). Areas along primary travel paths are known by many persons and, consequently, by more potential offenders (Beavon, Brantingham, \& Brantingham, 1994). Crime ought, then, to be concentrated on or near major highways (Beavon, Brantingham, \& Brantingham, 1994). Crime, fortunately, has not saturated the urban environment, and while crime may be concentrated on or near a major road, not all significant ways are sites for a lot of crime (Beavon, Brantingham, \& Brantingham, 1994).

\subsection{Methodology}

This research is a qualitative approach by field observation to investigate the physical environment of the snatch theft hotspot area. To identify the hotspot area for the investigation, snatch theft crime data should be gathered first from Polis Diraja Malaysia (PDRM). Snatch theft statistical data obtained in the year 2010 until 2015. From the statistical data, Selangor has the highest number of cases (5553 cases) compared to the others. Selangor is selected as a case study in this research since it has the most top record of snatch theft cases. Selangor consists of 15 districts by Polis Diraja Malaysia (PDRM) (Refer Table 1), the top three with the highest total of snatch theft cases in Selangor are Ampang Jaya with 1,809 cases; Petaling Jaya with 987 cases; and Subang Jaya with 825 cases. Thus, Ampang Jaya is selected to be a case study since it has the highest case reported.

Table 1. Statistical data of Snatch Theft According to Districts of PDRM in Selangor

\begin{tabular}{|c|c|c|c|c|c|c|c|}
\hline \multirow{2}{*}{ District } & \multicolumn{6}{|c|}{ Year } & \\
\hline & 2010 (cases) & 2011 (cases) & 2012 (cases) & 2013 (cases) & 2014 (cases) & 2015 (cases) & Total \\
\hline Ampang Jaya & 429 & 260 & 321 & 322 & 257 & 220 & 1809 \\
\hline Gombak & 67 & 8 & 5 & 5 & 1 & 3 & 89 \\
\hline Hulu Selangor & 6 & 1 & 2 & 5 & 3 & 10 & 27 \\
\hline
\end{tabular}




\begin{tabular}{|c|c|c|c|c|c|c|c|}
\hline Kajang & 16 & 1 & 79 & 127 & 150 & 128 & 501 \\
\hline Klang Selatan & 114 & 90 & 31 & 82 & 31 & 21 & 369 \\
\hline Klang Utara & 14 & 31 & 13 & 31 & 17 & 14 & 120 \\
\hline Kuala Langat & 25 & 12 & 4 & 6 & 9 & 8 & 64 \\
\hline Kuala Selangor & 23 & 14 & 2 & 1 & 2 & 4 & 46 \\
\hline Petaling Jaya & 135 & 79 & 82 & 183 & 153 & 355 & 987 \\
\hline Sabak Bernam & 42 & 19 & 17 & 15 & 21 & 27 & 141 \\
\hline Sepang & 13 & 7 & 6 & 4 & 11 & 8 & 49 \\
\hline Serdang & 66 & 82 & 30 & 50 & 22 & 41 & 291 \\
\hline Shah Alam & 102 & 43 & 7 & 6 & 3 & 2 & 163 \\
\hline Subang Jaya & 195 & 152 & 127 & 130 & 151 & 70 & 825 \\
\hline Sg. Buloh & - & - & - & 18 & 15 & 39 & 72 \\
\hline Total (Cases) & 1247 & 799 & 726 & 985 & 846 & 950 & 5553 \\
\hline
\end{tabular}

The data of Snatch theft in Ampang Jaya were transferred into a website called 'batchgeo' as shown in Figure 2. it can directly be detected on a map the reported cases. The excel file format of the reported cases is copied according to the year one by one and uploaded in the provided space. Then the data uploaded need to be validated and set the options according to the details in the excel file. This method is indeed fast and convenient rather than sorting the data manually. But it also has its limitation where it cannot be as accurate as doing it manually since it will be dependent on the data uploaded. The disadvantages of the data are that, the writing report is based on the victims' verbal communication rather than having an accurate and precise address of the incident happened.

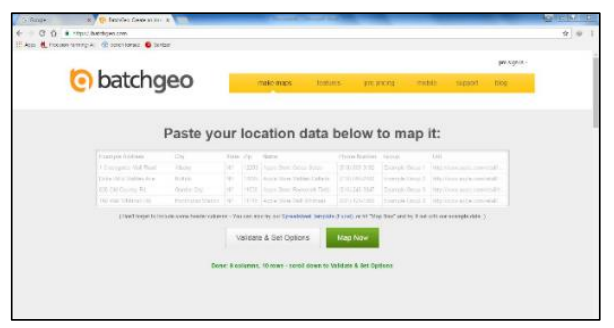

(a)

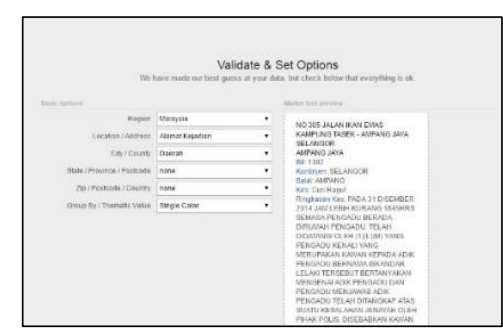

(b)

Fig. 2. (a) \& (b) Batchgeo Data Uploaded at www.batchgeo.com

The results obtained from batchgeo in Figure 3 is produced, and the snatch theft cases will be pointed in the computer-generated map according to the data from the police. The number of instances looked at particular places or street within the research area. Each led case on the produced map is represented as one case.

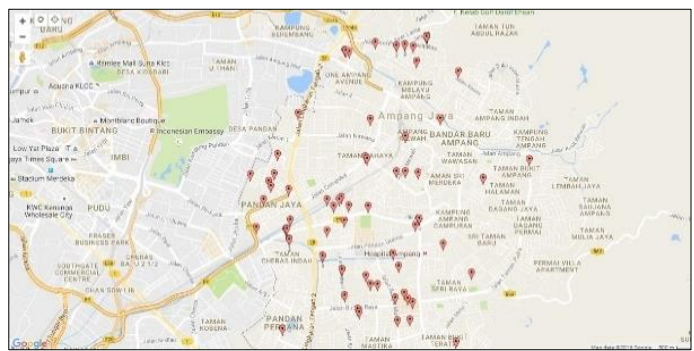

Figure 3. Map with Numbers of Snatch Theft Data

The area of snatch theft been located after the data has been inserted. These areas were then categorised into five different colourcoded, which are red, orange, yellow, light green and green to identify which city will be the hotspot area. Red colour represents an area with the highest number of snatch theft cases while green with the lowest or no snatch theft cases. Figure 4(a-f) shows the results of the hotspot map obtained from the year 2010 until 2015, respectively. The small black spots represent the number of cases according to the statistical data from PDRM. From Figure 4(a-f) the hotspot area is shown in red colour, and it is found that within Ampang Jaya territory, Pandan Indah is having the highest hotspot of snatch theft incidents from the year 2010 until 2015 . The case study area will be 
Pandan Indah which located within a local authority area of Ampang Jaya (refer to Figure 5. Zoom-in of the Pandan Indah). This area primarily consists of lands uses, such as commercial areas and residential areas.

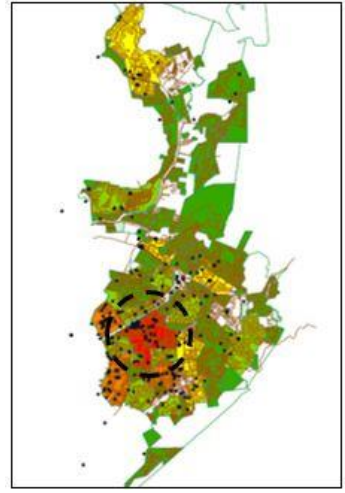

(a) 2010

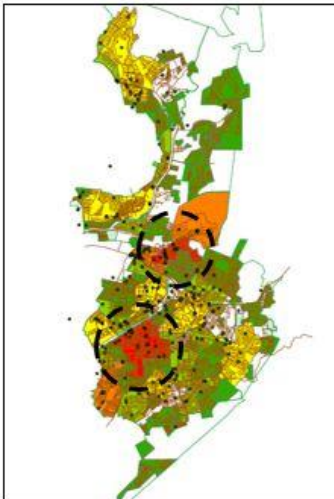

(d) 2013

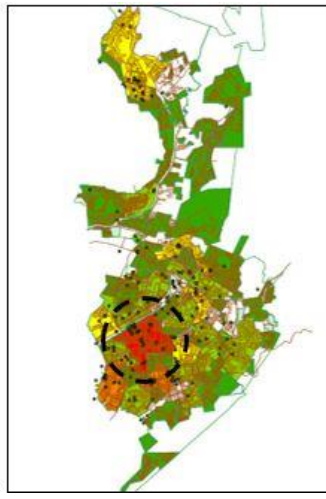

(b) 2011

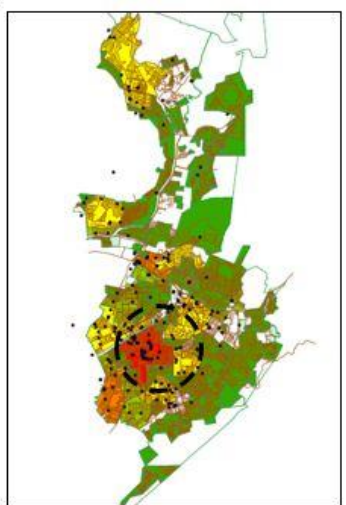

(e) 2014

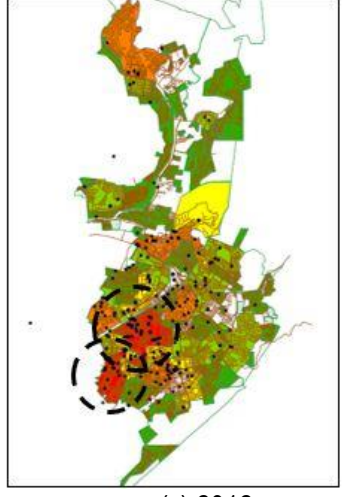

(c) 2012

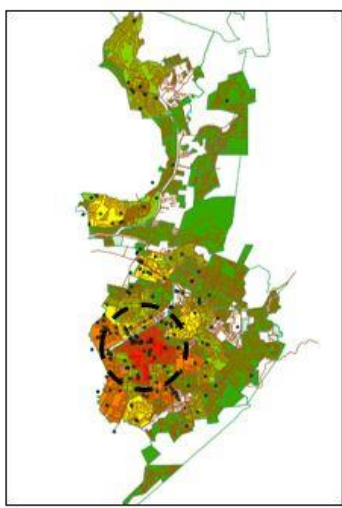

(f) 2015

\section{() Hotspot area}

Figure 4 (a-f). Snatch Theft Cases Distribution in Ampang Jaya From the Year 2010 until 2015

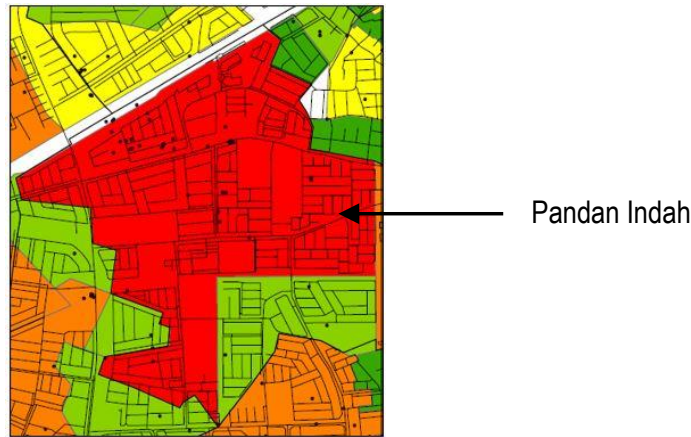

Figure 5. Pandan Indah in Red as Hotspot Area

\subsubsection{Field observation}

In the beginning, the map shows the hotspot areas within the highest recorded district, which is in Ampang Jaya. After that, it is further down towards the most top snatch theft hotspot areas according to the regions exists in Ampang Jaya such as Pandan Indah, Pandan Perdana, and so on. Then for the final step, it will narrow further down based on the snatch theft occurrence on the street. The field observation by using checklist form is used for the Crime Prevention through Environmental Design (CPTED) to assist in the data recording on the surrounding areas. The checklist is formed based on the previous scholars on physical environmental attributes of the CPTED. The checklist form consists of four dimensions which are territoriality, surveillance, access control and maintenance.

Regarding GIS mapping, the results show the most top area with snatch theft cases is Taman Pandan Indah neighbourhood area. Next, it is narrowed down to the street with the highest snatch theft cases. In this case, Jalan Pandan Indah 12 has the highest number of snatch theft incidents from the produced computer-generated GIS map based on the PDRM data. From Jalan Pandan Indah 12, a radius of 400-meter is used to conduct the field observation. This radius is divided by four spans from the middle road of Jalan Pandan Indah 12 starting with a 100 meter, 200 meters, 300 meters and 400 meters radii on the map. This method of every 100 meters of the range is selected and adapted to find a more precise, more accurate and detail observations on the physical environment. After that, 
only Jalan Pandan Indah 12 is selected, and from every snatch theft spot on the street, 50 meters radius is constructed to observe the physical elements that might contribute for the road to become a high snatch theft area.

\subsection{Result and Discussion}

As mentioned before, a 400-meter radius is used with a reference point at Jalan Pandan Indah 12 (Refer Figure 6). Where this specific distance of 400 meters is used as the distance to show the risk of burglary is communicable (Bowers, Johnson, \& Pease, 2004). This is because Jalan Pandan Indah 12 has the highest number of snatch theft incidents in the year 2015. The street pattern of the residential area in Taman Pandan Indah and the different neighbourhood are examined at this point. The analysis is done by evaluating four main principles in CPTED, surveillance, territoriality, access control and maintenance.

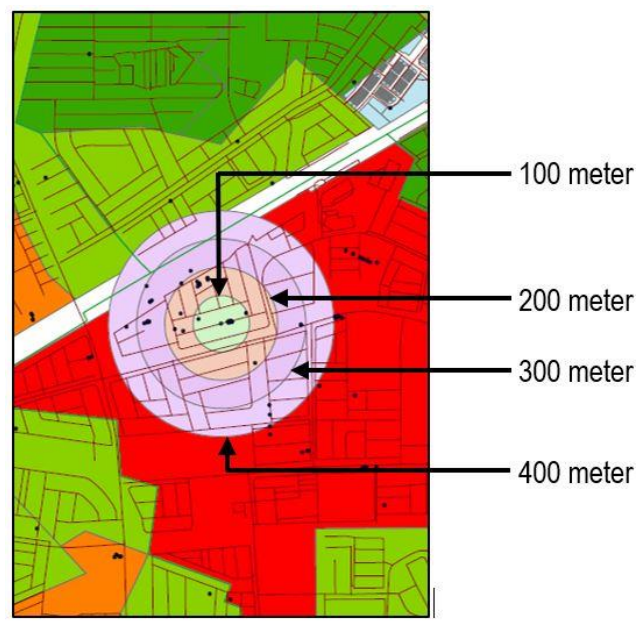

Figure 6. A 400-meter Radius was used for Field Observations

In this paper, the discussion focusing on the area of along Jalan Pandan Indah 12 (circle with light green colour) the highest snatch theft cases in 2015. There are six points of snatch theft hotspot, as shown in Figure 7.

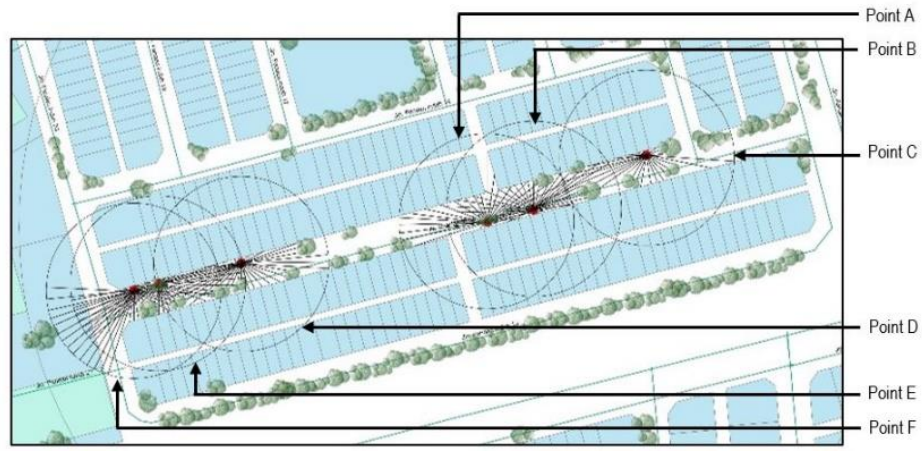

Figure 7. Visual Map Based on Street with High Snatch Theft Spots in 2015

Figure 7. shows the street with highest snatch theft cases in 2015, which is along Jalan Pandan Indah 12. Point A to Point $F$ indicates the places where snatch theft happened based on the PDRM data that has been sorted out by using GIS application. Each of this point is constructed with a 50 meters radius to examine the existing surroundings and what could have contributed to the snatch theft incidents. Visual lines are drawn from the snatch theft spots in a radial order. Targets located farther away were challenging to recognize or at least not given a fair chance of recognition rate. It is loosely defined as the most significant distance at which an object of specified characteristics can be seen and detected with the naked eye. The result of the six-point of hotspots is shown in Table 2. 
Table 2. The Six of Hotspot Snatch Theft Point and the Surrounding images

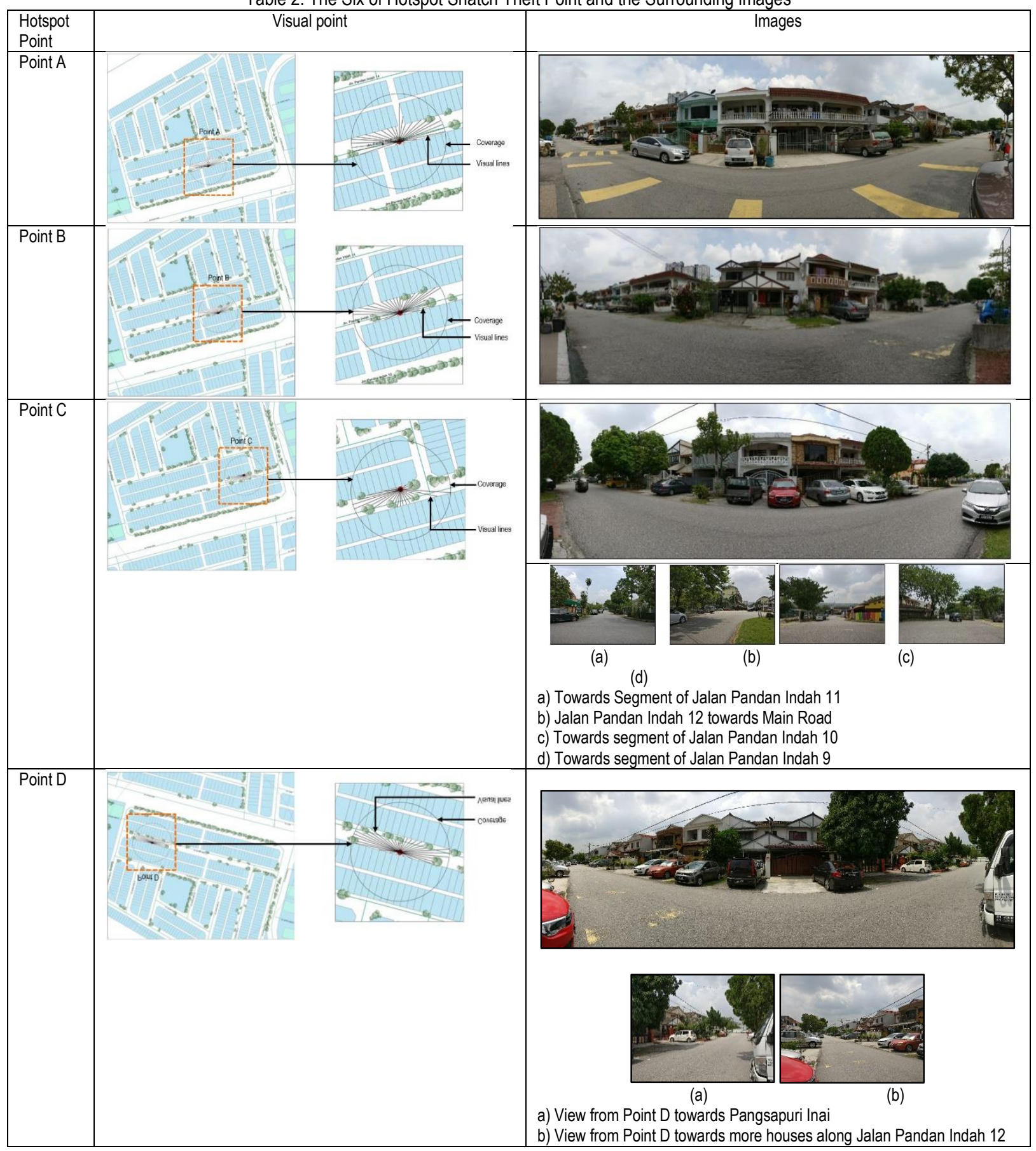




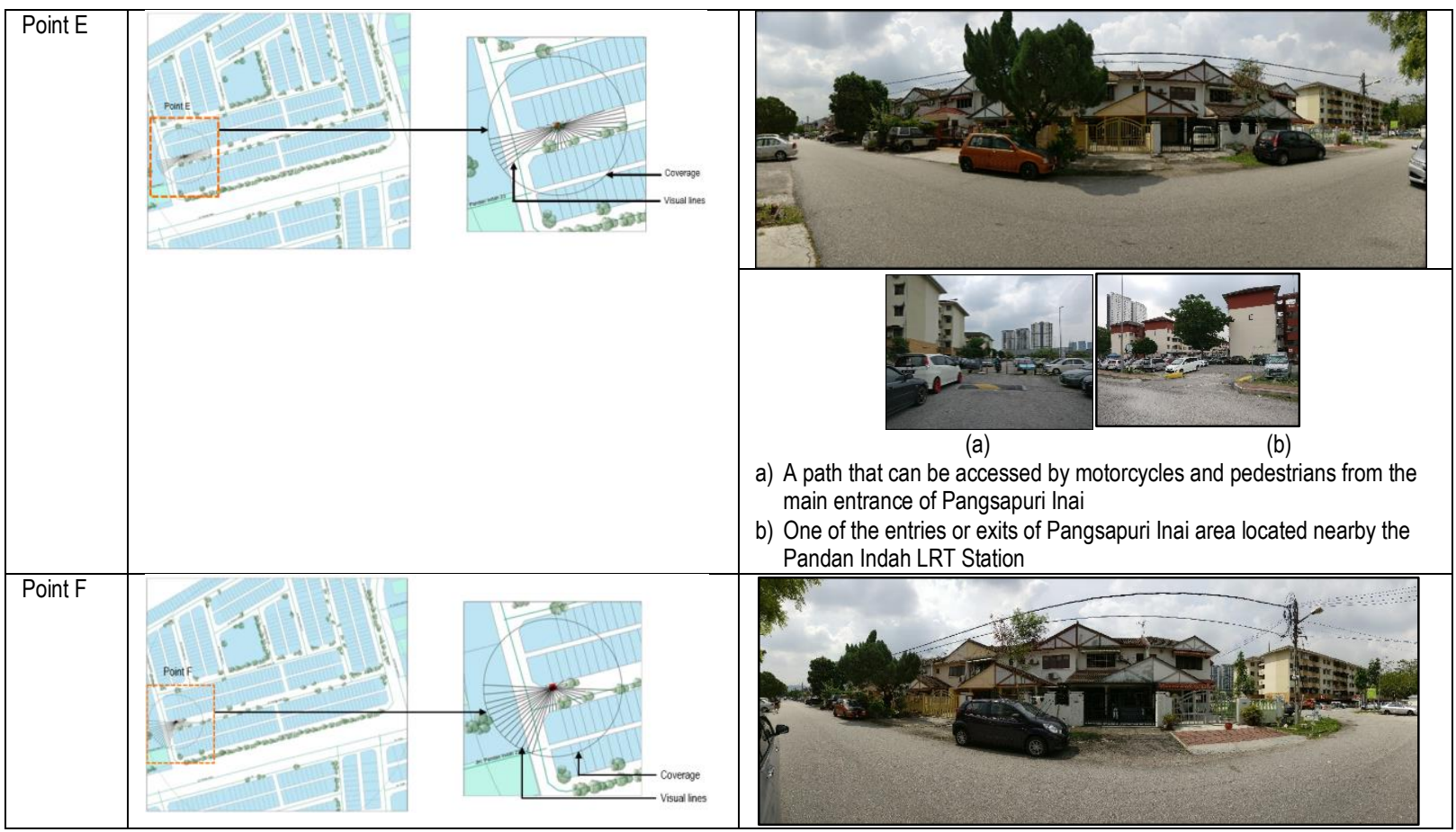

Point $\boldsymbol{A}$ is a point where the snatch theft incident took place. This point is located in the middle of Jalan Pandan Indah 12 and also located nearby the firebreaks of both sides of the house rows. From this point, the area around it, within 50 meters radius is examined. In terms of the natural surveillance, the area is not blocked by any overgrown vegetation which could block the view from the houses or form both sides of the street. Referring to the image, the side of the road, especially in front of the houses' gate, the view from the inside of the house could be blocked by the cars that are parked in front of it. Other than that, we will never know whether the houses' windows are equipped with curtains which the residents will not be able to realize what is happening on the outside of the house. Snatch theft could take this advantage since the residents might not be aware that the offenders are targeting anyone along the street and there isn't any CCTV installed at any of the houses within this 50 meters radius distance from the snatch theft spot. As for the access control, this snatch theft spot is located along a straight street and can be accessed by anyone and any vehicles. Point $A$ also is located nearby the firebreak of the houses row on the North towards the Jalan Pandan Indan 14 and South towards Jalan Pandan Indah 10. If a snatch theft were to commit snatch activity, they could use the firebreaks either use it as an entry or exit, other than escaping using the straight street of Jalan Pandan Indah 12. For territoriality, the area only has clear sightlines of the houses' gates since this neighbourhood consists of terrace houses and do not have any safe space. The maintenance of this area mainly is proper or well-maintained in terms of the cleanliness of the street.

Point $B$, the area from the snatch theft spot within the 50 meters radius, has more vegetation around it. The area within the radius seems to have a more unobstructed from the snatch theft spot. Some of the vegetation exists in this area has less tall vegetation which is visible for the public to see the surrounding. Within this radius also, there is no CCTV installed for the neighbourhood surveillance. Snatch theft spot Point B also located nearby both of the firebreaks as Point A where snatch theft can have alternative escape routes. The firebreak on towards the north is nearer to the Point $B$. The firebreak also consists of a locked fence to prevent any outsiders other than the residents from using the area at the back of their houses. This is also one of the precaution steps taken by the residents in the Taman Pandan Indah neighbourhood. As for the territoriality, it can be seen that the sightline is divided by the houses' gate and the street. There isn't any warning sign in neither in this neighbourhood nor Jalan Pandan Indah 12 which has been identified as the frequent street with snatch theft incidents in 2015 based on the statistical data. This area is in good condition or well-maintained in terms of the cleanliness of the road, and there is hardly any blocked or hiding area for any snatch theft to hide before committing the crime.

The Point $\boldsymbol{C}$ has more vegetation around it from the snatch theft spot within the 50 meters radius. Most of the plant within this radius is almost as tall as the two-storey terrace house itself which can block or limit the view of the natural surveillance by the public, especially from the houses. Cars also are parked in front of the houses by the residents of Taman Pandan Indah which could limit the view from the inside of the house towards the street. Other than that, the existence of the vegetation from this area also could provide hiding places for the offenders before they commit snatch activity. Point $C$ also located nearby a street segment towards the Jalan Pandan Indah 11 , Jalan Pandan Indah 9, Jalan Pandan Indah 10 and the section towards the main road from this neighbourhood. The Point $\mathrm{C}$ has several escape routes to enter and escape from the Jalan Pandan Indah 12. Since snatch theft often uses a motorcycle to commit snatch activity, it would be convenient for them to flee due to the small motorcycle size. Jalan Pandan Indah 12 is a linear street. It also can be accessed by anyone at any time without knowing whether those are using this road are from this neighbourhood or merely used it as an alternative street to avoid the waiting time at the traffic lights at the main road junction. In terms of territoriality, especially at the intersection from the main towards the neighbourhood of Jalan Pandan Indah 12, there is no signage to indicate the name of the Taman Pandan Indah neighbourhood area. The maintenance of this area mostly is well-maintained except for the untrimmed vegetation around 
it. Some vegetation could block the view from the public at this point - with dense shady trees and shrubs. There is also a car parked at the corner of the street towards the Jalan Pandan Indan 11. The area with these conditions could be a hiding place for the snatch theft before they commit the snatch activities. A clearer and cleaner eye-level viewed area need to be done to reduce the potential hiding places for the offenders such as snatch theft. People who are walking or pedestrian would not be able to see or predict what is in front of them if the view is blocked with untrimmed or overgrown vegetation. Hence, the maintenance in terms of the landscape plays an important role to avoid hiding places for the offenders and to give a right eye view towards every part of the streets.

Next snatch theft spot is Point $\boldsymbol{D}$. The area within the 50 meters radius also has a more unobstructed view and lesser vegetation around it. There is no CCTV installed within this area. There are more cars parked along both sides of the street of Jalan Pandan Indah 12 which indirectly limit the view or natural surveillance that could provide by the residents of this area of the neighbourhood. There is some vegetation that also contributes to the limitation of natural surveillance since the plant is overgrown and almost as tall as the houses. Although the trees provide shades for the pedestrian, who is using this street, the lower trunk of the trees should be cut off to give a more unobstructed view within a certain distance. The view towards Pangsapuri Inai has a limited view from Point $D$ since the vegetation is denser, and vehicles such as cars and lorry are parked from this view. If people or pedestrian are walking from the road segment of Pangsapuri Inai towards the Jalan Pandan Indah, 12 might not be aware if snatch theft or any other crime offenders are hiding among those vehicles since the view is blocked. The residents from inside the house also might not be able to see outside clearly since cars are parked in front of the houses' gate and overgrown vegetation could limit the vision too. In terms of accessibility, Jalan Pandan Indah 12 is frequently used by anyone either the residents of this neighbourhood or outsiders to avoid the waiting time of the traffic lights at the junction of the Jalan Pandan Indah main road. Since this neighbourhood is not guarded or a gated residential area, anyone can access Taman Pandan Indah neighbourhood which could also be an opportunity for the snatch theft to survey this neighbourhood before they are committing the crime. Jalan Pandan Indah 12 is a linear street and has easy navigation for the snatch theft to escape or choose which route to survive since there are firebreaks between the house blocks. Besides, from Point $D$, it is easier for snatch theft to avoid if snatch incidents were to happen because they can flee towards the main road and disappear of the victim and public. The territoriality within the 50 meters radius is the same as Point A-C where clear sightlines of the resident's territory are divided by the houses' gate and the street of Jalan Pandan Indah 12. From this point also, there is no signage as a reminder for the pedestrians to be aware of the snatch theft. Since this neighbourhood has been a hotspot area snatch theft based on the police data, there should at least to have two or three warning signage to keep people alert and aware of their surroundings. The maintenance generally is proper, and the street is clean from any sight of trash or rubbish except the overgrown vegetation such as trees and shrubs which could limit the eye-level vision of the pedestrians who use every street in this neighbourhood.

The fifth point is the Point $E$. This area is located at the third and fourth houses from the street segment towards Jalan Pandan Indah 12. There is no CCTV installed for the neighbourhood surveillance. From the Point E towards the Jalan Pandan Indah 12, It has a more precise and clearer picture. There is no thick and overgrown vegetation as other snatch theft points along Jalan Pandan Indah 12. Nevertheless, there are still cars parked along this street which could contribute to the hiding places for the snatch theft before they commit the snatch activities. As mentioned earlier, even though this area seems to have a more unobstructed view within the eye level, it is not known whether the view from the terrace houses is blocked with curtains at the windows or any objects from the windows of the flat block which can be seen from the Point $E$. From the accessibility aspects, Point $E$ is located just a few houses from the street segment. Point $E$ is having the nearest access and escape route towards the Jalan Pandan Indah main road since that is one of the entries to access this neighbourhood of Taman Pandan Indah. Other than that, the snatch theft also could escape through Jalan Pandan Indah 10 or by entering the Pangsapuri Inai since there are ways to get away from the neighbourhood that especially fit for the size of a motorcycle. In terms of territoriality from Point $E$ of snatch theft spot, just like any other points along Jalan Pandan Indah 12, there are clear sightlines distinguished the area of the terrace houses which are the gates and wall fence. There is also clear territorial that divides the Taman Pandan Indah neighbourhood and Pangsapuri Inai.

Last but not least, the Point $\boldsymbol{F}$ of snatch theft spot along Jalan Pandan Indah 12. Both of Point $E$ and Point $F$ are located nearby each other, which is with a house different. Point $F$ has a more transparent view towards the block of Pangsapuri Inai. Point $F$ is located exactly at the street segment of Jalan Pandan Indah 12, which has the same access and escape route for the snatch theft after committed snatch activities as the Point $E$ on the previous discussion. From the view of Point $F$, there is a car parked in front of the house and could block the view from the inside of that particular house. This area within the 50 meters radius, almost does not have any overgrown vegetation which could limit the vision of the pedestrian walking along this street, especially in front of the house. The people of the pedestrian who are walking within this radius could at least predict what is in front of them or can see the surrounding. Even though any overgrown vegetation is not blocking the area in front of the houses, the other parts of the city within the radius still has a place that can be hidden for the snatch theft for instance on the left side with a car parked and vegetation area. In terms of accessibility and the territoriality of the Point $F$, it just has the same evaluation and observation as the Point $E$ as discussed earlier since both of the points are located next to each other.

\subsection{Conclusion}

Usually, snatch theft incidents tend to happen in the urban area such as commercial and public areas rather than the residential areas. This might be because of the street design in the neighbourhood which has easy access and escape routes for the snatch offenders. Most of the streets in Pandan Indah are the straight or linear street that is connected directly with the main road, Jalan Pandan Indah, which can be accessed by anyone at any time. Even though this area is residential, the residents in the neighbourhood do not tend to be outside of the house all the time as compared to the commercial sector or public spaces which can provide informal surveillance by the public. This might be one of the advantages for the snatch theft to commit the crime within the neighbourhood. If it were to relate the 
Newman's (1972) and Jacobs' (1961) theories with the study of the snatch theft hotspot study, the results from the study shows that the snatch theft incidents happened in residential area where the area clearly has its territory and based on the street pattern layout, the study area has as high accessibilities as gridiron street pattern layout. Based on this, the city is having its territory, which is also having high surveillance from the public coming to and from the district. Although the study area has similar features as described by Newman and Jacobs, the city still ends up with high snatch theft incidents happened and a hotspot area. Besides that, this neighbourhood also is connected with the transit hub, LRT Pandan Indah, where people are walking, cycling or driving to use the facility provided. It is noted that the victims of the snatch incidents are often to be the pedestrians who are walking. The victims here might be the people who are walking to the LRT station going to work or coming back home from work. Within this neighbourhood, if the street design layout to be observed, it was found that the area has a confusing street layout where there is access below the elevated main road from the other neighbourhood to this neighbourhood. Generally, we can never see or know there is access from the different community to this neighbourhood. It seems as if the offenders who are the snatch thefts for this study, might be someone that already knows the layout of the neighbourhood area and the potential victims within it. Snatch theft activities usually happen before dawn and in the late evening and frequently occurs around the pathway near to the roadside, transit areas, and area with less or no people.

For the next research, it is recommended to investigate the perception of safety and fear of crime among the residents. This is to identify the feeling of safety of the people living in the area and to identify the possibility the lifestyle is one factor that is contributing to the snatch theft crime.

\section{Acknowledgements}

In realizing this study, the researchers would like to thank the Royal Malaysian Police (PDRM), Ministry of Higher Education by the Malaysian Government to support this research by the Research Acculturation Collaborative Effort (RACE) of (600RMI/RACE16/6/2(3/2015)).

\section{References}

Abdullah, A., Razak, N. A., Salleh, M. N. M., \& Sakip, S. R. M. (2012). Validating Crime Prevention through Environmental Design Using Structural Equation Model. Procedia - Social and Behavioral Sciences, 36(6), 591-601.

Anderson, J. M., Macdonald, J. M., Bluthenthal, R., \& Ashwood, J. S. (2013). Reducing Crime by Shaping the Built Environment with Zoning: An Empirical Study of Los Angeles, Vol. 161:(699), 699-756. Retrieved from http://scholarship.law.upenn.edu/cgi/viewcontent.cgi?article=1016\&context=penn_law_review.

Beavon, D. J. K., Brantingham, P. L., \& Brantingham, P. J. (1994). The influence of Street Networks on the Patterning of Property Offenses. Crime Prevention Studies, Vol 2, 115-148. Retrieved from http://www.popcenter.org/library/crimeprevention/volume_02/06beavon.pdf.

Brantingham, P., \& Brantingham, P. (1984). Patterns in Crime. National Criminal Justice. Retrieved from https://www.ncjrs.gov/App/Publications/abstract.aspx?ID=110611

Bowers, K. J., Johnson, S. D., \& Pease, K. (2004). Prospective hot-spotting: The Future of Crime Mapping. British Journal of Criminology, 44(5), $641-658$.

Chowdhury, U. (2014). Street Crime and Physical Environment. The Perception of Local People regarding Security Feelings, 3(1), 66-81.

Davies, T., \& Johnson, S. D. (2015). Examining the Relationship Between Road Structure and Burglary Risk Via Quantitative Network Analysis. Journal of Quantitative Criminology, 31(3), 481-507.

Faizah, M. L. (2015). Ke Arah Pengurangan Indeks Jenayah Jalanan di Pusat Bandar Kuala Lumpur. Towards reducing the street crime index of Kuala Lumpur City Centre, 4(4), 97-107.

Fujii, T., Sasaki, Y., \& Kishimoto, T. (2013). Estimation of the Risk of Snatching in a Suburb: Case study of Soka, Saitama prefecture, Japan. Proceedings of the 9th International Space Syntax Symposium, Seoul, 111, 1-111.

Greenberg, S. W., \& Rohe, W. M. (1984). Neighborhood design and crime: A test of two perspectives. Journal of the American Planning Association, 50(1), 48-61.

Jacobs, J. (1961). The Death and Life of Great American Cities. In New York, Random House, Inc.

Lee, T. (1970). Perceived Distance as a Function of Direction in the City. Environment and Behavior, 2(1), 40-51.

Lowe, J. C., \& Moryadas, S. (1975). The Geography of Movement. Boston: Houghton Mifflin.

Liggett, R., Loukaitou-sideris, A., Iseki, H., \& Candidate, D. (2003). Protecting Against Transit Crime, 139-156.

Mustafa, A. N. \&, \& Sakip, S. R. (2017). Street Pattern Effects on Snatch Incidents. Malaysian Journal of Sustainable Environment, 2(1), 137-160. https://doi.org/https://doi.org/10.24191/myse.v2i1.5588.

Monk, K., Heinonen, J. A., \& Eck, J. E. (2010). Street Robbery the Problem of Street Robbery What This Guide Does and Does Not Cover. Retrieved from http://www.popcenter.org/problems/street_robbery/print/.

Newman, O. (1972). Defensible space. New York: Macmillan. 
Nubani, L., \& Wineman, J. (2005). The Role of Space Syntax in Identifying the Relationship Between Space and Crime. Proceedings 5th International Space Syntax Symposium, 413-422.

OSAC. (2015). Malaysia 2015 Crime and Safety Report, 1-8. Retrieved from https://www.osac.gov/pages/ContentReportPDF.aspx?cid=17215

PDRM, Polis Diraja Malaysia. (2016). Statistik Jenayah Ragut.

Thomson, J. M. (1977). Great Cities and Their Traffic. Harmondsworth, UK: Penguin Books.

Weisel, D. L., Gouvis, C., \& Harrell, A. V. (1994). Addressing Community Decay and Crime: Alternative Approaches and Explanation. Urban Institute. Washington.

Yew, E. L. (2012). Situation Analysis of Snatch Theft Issue in Malaysia. Multimedia University (MMU). 